\title{
Clinical outcomes of active specific immunotherapy in advanced colorectal cancer and suspected minimal residual colorectal cancer: a meta-analysis and system review
}

Benqiang Rao ${ }^{1,4}$, Minyan Han², Lei Wang ${ }^{1,4}$, Xiaoyan Gao ${ }^{3}$, Jun Huang ${ }^{1}$, Meijin Huang ${ }^{1}$, Huanliang Liư Jianping Wang ${ }^{1,4^{*}}$

\begin{abstract}
Background: To evaluate the objective clinical outcomes of active specific immunotherapy (ASI) in advanced colorectal cancer (advanced CRC) and suspected minimal residual colorectal cancer (suspected minimal residual CRC).

Methods: A search was conducted on Medline and Pub Med from January 1998 to January 2010 for original studies on ASI in colorectal cancer (CRC). All articles included in this study were assessed with the application of predetermined selection criteria and were divided into two groups: ASI in advanced CRC and ASI in suspected minimal residual CRC. For ASI in suspected minimal residual CRC, a meta-analysis was executed with results regarding the overall survival (OS) and disease-free survival (DFS). Regarding ASI in advanced colorectal cancer, a system review was performed with clinical outcomes.

Results: 1375 colorectal carcinoma patients with minimal residual disease have been enrolled in Meta-analysis. A significantly improved OS and DFS was noted for suspected minimal residual CRC patients utilizing ASI (For OS: HR $=0.76, P=0.007$; For DFS: HR $=0.76, P=0.03$ ). For ASI in stage II suspected minimal residual $C R C$, OS approached significance when compared with control $(H R=0.71, P=0.09)$; however, the difference in DFS of ASI for the stage II suspected minimal residual $C R C$ reached statistical significance $(H R=0.66, P=0.02)$. For $A S I$ in stage III suspected minimal residual CRC compared with control, The difference in both OS and DFS achieved statistical significance (For OS: HR $=0.76, \mathrm{P}=0.02$; For DFS: $\mathrm{HR}=0.81, \mathrm{P}=0.03$ ). 656 advanced colorectal patients have been evaluated on ASI in advanced CRC. Eleven for CRs and PRs was reported, corresponding to an overall response rate of 1.68\%. No serious adverse events have been observed in 2031 patients.

Conclusions: It is unlikely that ASI will provide a standard complementary therapeutic approach for advanced CRC in the near future. However, the clinical responses to ASI in patients with suspected minimal residual CRC have been encouraging, and it has become clear that immunotherapy works best in situations of patients with suspected minimal residual CRC.
\end{abstract}

\section{Background}

Colorectal cancer (CRC) is the third most common cancer in females and the fourth most common in males worldwide. CRC is the fourth and fifth most frequent cause of cancer-related deaths depending on gender [1].

\footnotetext{
*Correspondence: wangjpgz@yahoo.com.cn

'Colorectal Surgery Department, The Sixth Affiliated Hospital, Sun Yat-sen University, Guangdong 510655, PR China

Full list of author information is available at the end of the article
}

Surgery is the cornerstone of CRC therapy. Unfortunately, more than $20 \%$ of patients with CRC have metastatic disease at the time of diagnosis [2]. Although the most common indication for liver resection in developed countries is metastatic CRC, surgery can only be performed in $20 \%$ patients [3].The prognosis of patients with resectable tumor depends on the disease stage. The 5 -year survival for patients with CRC following surgery varies between $80-90 \%$ for stage I, $70-75 \%$ for stage II, 
$35-50 \%$ for stage III and $<7 \%$ for stage IV disease [4]. Despite the fact that $80 \%$ of CRC patients have complete macroscopic clearance of the tumor by surgery, $50 \%$ of CRC patients will relapse [5]. This is presumably due to the presence of micro-metastasis at the time of surgery. In general, the 5-year survival for patients with CRC ranges from $50-60 \%$ over the past 30 years [6].

Avenues for the clinical testing of rationally designed vaccination strategies, including immunotherapy, are being explored as complementary treatments. Recent advances in immunology and molecular biology have opened new fronts against cancer. Early strategies used for treatment of CRC included non-specific immunotherapies, such as exogenous immunostimulants, cytokines, adoptive transfer of non-specific immune effector cells, and the inhibition of negative immune regulatory pathways and tumor-derived immune suppressive molecules. Several studies have evaluated the clinical results to nonspecific immunotherapies in patients with CRC, but most of studies revealed no improvement in the response rate, progression-free survival, or overall survival [7-9]. In general, nonspecific approaches have yielded limited results in the treatment of CRC. Since the discovery of tumor-associated antigens during the early 1990s, rapid progress has been made in identifying antigens and describing immune interactions in cancer patients. Many clinical trials have been conducted using active specific immunotherapy (ASI) in CRC, including autologous tumor cell vaccines, define-tumor protein vaccines, monoclonal antibodies and anti-idiotype vaccines, multi- peptide vaccines, viral vector vaccine, DC vaccine, and naked DNA vaccine[10].

However, despite an abundance of preclinical data, relatively little is known regarding the efficacy of ASI in CRC. Early clinical trials of ASI against CRC have provided mixed results, which led to a controversy flare-up over the clinical efficacy of ASI in CRC [11,12]. In the present report, we focused on meta-analysis of ASI to patients with suspected minimal residual colorectal cancer (suspected minimal residual CRC), and reviewed the objective clinical outcomes of ASI in advanced colorectal cancer (advanced CRC) during the past 12 years.

\section{Methods}

\section{Literature Search Strategy}

A search was conducted on Medline and PubMed from January 1998 to January 2010 for original studies on ASI in CRC, Using the following keywords: "colorectal" OR "colon" OR "rectal" AND "cancer" OR "carcinoma" AND" vaccine "OR "vaccination" OR "immunization". Review papers were also examined for published results. We avoided duplications of data by examining the body of each publication and the names of all authors. When such duplications were identified, the latest version was included into our study.

\section{Selection Criteria}

Inclusion criteria included all articles concerning histopathologically defined CRC treated by ASI. At the beginning of ASI, a minimum of 4-weeks should have elapsed from the time of completion of prior chemotherapy and/or radiation therapy. No concurrent chemotherapy, radiotherapy, or drugs which affect immune function (such as glucocorticoids, Cimetidine, etc.) should have been administered during ASI or follow-up. Studies were limited to human trials, and in the English language. Data regarding tumors without specific documentation of colorectal origin were not included. However, these exclusions were not applied if isolated data regarding CRC are provided. Case studies, review articles, and studies involving fewer than three patients were excluded to allow for consistent results.

\section{Data Extraction and Quality Assessment}

Two reviewers independently selected the trials and performed the data extraction. Discrepancies were resolved by discussion among reviewers. Because the outcome parameters are different in advanced CRC and suspected minimal residual CRC, we divided the articles into two groups: ASI in advanced CRC (a measurable tumor burden) and ASI in suspected minimal residual CRC (patients had undergone complete resection for primary tumor or metastasis disease without evidence of remaining macroscopic disease). Clinical outcomes to evaluate ASI in suspected minimal residual CRC were OS and DFS, and clinical outcomes of ASI in advanced CRC were complete response (CR), partial response (PR), mixed or minor response $(\mathrm{MR})$ and stable disease $(\mathrm{SD})$, which had to meet the WHO criteria. To avoid ignoring small benefits that could add up to a clinically relevant result, the clinical benefit rate (CBR) has been introduced in this report. The CBR represents the sum of CR, PR, MR, and SD rates. Thus, for subset analysis, the CBR was calculated as the sum of $C R, P R, M R$, and $S D$ based on the various vaccine formulations, the route of vaccination, and adjuvants [13]. For the Meta-analysis of ASI in suspected minimal residual CRC, the overall quality of each study was assessed in accordance with the Jadad format[14]. A grading scheme $(\mathrm{A}, \mathrm{B}$, and $\mathrm{C})$ is used to classify four main aspects: 1 ) quality of randomization, 2) quality of allocation concealment, 3) quality of blinding, and 4) quality of the description of withdrawals and dropouts. The grades are described as thus: A) adequate, with correct procedures, B) unclear, without a description of methods, and C) inadequate procedures, methods, or information. Based on these four criteria, the studies could be divided into three groups. "A" studies had a low risk of bias for studies and were scored 
with A grades for all items; "B" studies had a moderate risk of bias for studies with one or more B grades; "C" studies had a high risk of bias and were those with one or more $\mathrm{C}$ grades.

\section{Statistical Analysis}

With regards to ASI in advanced CRC, a post hoc explorative analysis was performed to calculate the overall response rate of ASI as well as the clinical benefit rate, based on the various vaccine formulations, the route of vaccination, and adjuvants. For the ASI in suspected minimal residual CRC, statistical analysis was carried out using Review Manager (version 5.0) provided by The Cochrane Collaboration. Dichotomous data were presented as relative risk (HR) and continuous outcomes as weighted mean difference (WMD), both with 95\% confidence intervals (CI). The overall effect was tested using $\mathrm{Z}$ scores, with significance being set at $\mathrm{P}<0.05$. Meta-analysis was performed using fixed-effect or random-effect methods, depending on absence or presence of significant heterogeneity [15]. Statistical heterogeneity between trials was evaluated by the chi-squared and I square $\left(\mathrm{I}^{2}\right)$ tests, with significance being set at $\mathrm{P}<0.10$. In the absence of statistically significant heterogeneity, the fixed-effect method was used to combine the results. When heterogeneity was confirmed $(P \leq 0.10)$, the random-effect method was used.

\section{Results}

Quantity of Evidence

A total of 789 studies were identified by the searches. By scanning titles and abstracts, 548 redundant publications, reviews and case reports were excluded. After referring to full texts, 192 studies which did not satisfy the inclusion criteria were removed from consideration. A total of 49 studies were left for analysis which involved 2031 patients, of whom 1375 (6 studies) were included in ASI for suspected minimal residual CRC group, and 656 (43 studies) were included in ASI for advanced CRC group.

Table 1 shows the characteristics of the six trials included in the meta-analysis [16-21]. Three of the six trials reported data for 7 years follow-up, other three studies followed up for 1 year, 5 years and 7.6 years respectively. All six studies were randomized, three studies mentioned the concealment of allocation clearly in the randomization process, and two studies mentioned withdrawal rates; however, none of the trials was blinded. Accordingly, we considered two studies as category $\mathrm{B}$, and four as category $\mathrm{C}$.

Table 2 shows the characteristics of the 43 trials included in ASI for advanced CRC group [22-64]. Among 43 studies, all had clearly stated inclusion and exclusion criteria. In addition, all studies were described with comparable baseline characteristics of ASI, including the number of evaluated CRC patients, the type of vaccine, the route of vaccination, adjuvants, the toxicity, and the objective clinical responses.

\section{Meta-analysis of ASI in suspected minimal residual CRC}

The OS at the end of treatment for ASI in patients with suspected minimal residual CRC is shown in Table 1. For stage I-IV suspected minimal residual CRC, statistically significant heterogeneity was detected $($ Tau $2=0.03$, Chi $2=11.13$,

Table 1 Clinical trials of ASI in suspected minimal residual CRC

\begin{tabular}{|c|c|c|c|c|c|c|}
\hline \multirow[t]{2}{*}{ Ref } & \multirow[t]{2}{*}{ ASI } & \multirow[t]{2}{*}{ Stage of patient } & Overall Survival & Disease-free Survival & \multirow{2}{*}{$\begin{array}{l}\text { Follow up } \\
\text { (year) }\end{array}$} & \multirow[t]{2}{*}{ Jadad's grades } \\
\hline & & & \multicolumn{2}{|c|}{ No. of events/no. of subjects } & & \\
\hline \multirow[t]{4}{*}[21]{} & ATC & Stage II & Con:31 of 109 & Con:35 of 109 & 7.6 & B \\
\hline & & & Exp:16 of 73 & Exp:18 of 73 & & \\
\hline & & Stage III & Con:26 of 44 & Con:28 of 44 & & \\
\hline & & & Exp:15of 33 & Exp:15 of 33 & & \\
\hline \multirow[t]{4}{*}[22]{} & ATC-BCG & Stage \| & Con:21 of 77 & Con:29 of 77 & 5 & C \\
\hline & & & Exp:14 of 80 & Exp:17 of 80 & & \\
\hline & & Stage III & Con:12 of 40 & Con:17 of 40 & & \\
\hline & & & Exp:16of 44 & Exp:20 of 44 & & \\
\hline \multirow[t]{2}{*}[23]{} & ATV-NDV & Stage I-IV & Con:16 of 25 & $\mathrm{NO}$ & 7 & C \\
\hline & & & Exp:12of 25 & & & \\
\hline \multirow[t]{2}{*}[24]{} & $17-1$ & Stage III & Con:48 of 76 & Con:54 of 76 & 7 & B \\
\hline & Antibody & & Exp:39 of 90 & Exp:50 of 90 & & \\
\hline \multirow[t]{2}{*}[25]{} & ATC & Stage I-IV & Con:146 of 257 & NO & 7 & C \\
\hline & & & Exp:135 of 310 & & & \\
\hline \multirow[t]{2}{*}[26]{} & ATC & Stage IV & Con:48 of 50 & $\mathrm{NO}$ & 1 & C \\
\hline & & & Exp:20 of 42 & & & \\
\hline
\end{tabular}

Abbreviations: Ref, reference; ASI, active specific immunotherapy; Con, control group; Exp, ASI experiment group; ATC, antilogous tumor cells; NDV, newcastle disease virus; No, not done. 
Table 2 Clinical trials of ASI in advanced CRC

\begin{tabular}{|c|c|c|c|c|c|c|c|}
\hline Ref & Vaccine & Adjuvant & Route & Patients & $\mathrm{CR}+\mathrm{PR}$ & MR & SD \\
\hline$[27]$ & Anti-ld $3 \mathrm{H} 1$ & i.c & $\mathrm{AH}$ & 23 & 0 & 0 & NR \\
\hline$[28]$ & $\mathrm{CEA} / \mathrm{HbsAg-CMV}$ & i.m & $\mathrm{HBsAg}$ & 17 & 0 & 0 & 0 \\
\hline [29] & DC-CEA peptid & i.v & No & 10 & 1 & 1 & 2 \\
\hline [30] & ALVAC(CEA-B7.1) & i.m & ALVAC/B7.1 & 13 & 0 & 0 & 2 \\
\hline [31] & DC-CEA peptid & i.v & No & 7 & 0 & 0 & 1 \\
\hline$[32]$ & Auto-tumor & i.d & NDV & 13 & 4 & 0 & 8 \\
\hline [33] & DC-CEA peptid & i.t & No & 10 & 0 & 0 & 2 \\
\hline [34] & Virus CEA & S.C & GM-CSF\IL-2 & 11 & 0 & 0 & $\mathrm{NI}$ \\
\hline [35] & Virus CEA & i.d/s.c & Tricom/GM-CSF & 35 & 0 & 0 & 14 \\
\hline$[36]$ & DC-CEA peptid & S.C & No & 7 & 0 & 0 & 2 \\
\hline$[37]$ & SART3 peptide & S.C & IFA & 12 & 0 & 0 & 1 \\
\hline [38] & DC-CEA transfected & i.v+id & $\mathrm{IL}-2$ & 11 & 0 & 0 & 0 \\
\hline [39] & DC-CEA peptid & s.c+id & Tricom & 11 & 0 & 0 & 6 \\
\hline$[40]$ & $\mathrm{DC}+$ tumor RNA & i.v & $\mathrm{KLH}$ & 15 & 0 & 0 & 0 \\
\hline [41] & DC+MAGE3 peptide & i.v & No & 3 & 0 & 1 & 0 \\
\hline$[42]$ & SART-IcK-CyB multi peptide & S.c & Montanideisa-51 & 10 & 0 & 1 & 1 \\
\hline$[43]$ & Survive peptide & S.C & No & 17 & 0 & 1 & 3 \\
\hline$[44]$ & DC + CEA peptide & s.c/i.d & No & 11 & 0 & 0 & 3 \\
\hline$[45]$ & ALVAC expressing CEA+B7.1 & i.d & B7.1 & 28 & 0 & 0 & 7 \\
\hline$[46]$ & Autologous hemoderivative & S.C & GM-CSF & 50 & 0 & 0 & 26 \\
\hline$[47]$ & DC+allogeneic tumor cell lysate & i.d & No & 17 & 0 & 0 & 4 \\
\hline$[48]$ & Trovax & i.m & MVA & 17 & 0 & 0 & 5 \\
\hline [49] & P53-SLP & S.C & No & 10 & 0 & 0 & 4 \\
\hline$[50]$ & tumor lysate pulsed-Dc & i.t & $\mathrm{THI}$ & 8 & 0 & 0 & 4 \\
\hline$[51]$ & Aex+GM-CSF & S.C & GM-CSF & 20 & 0 & 1 & 1 \\
\hline$[52]$ & DC+MHC-I peptide & i.d & IFN-[r]/GM-CSF & 11 & 0 & 0 & 0 \\
\hline [53] & Glutaraldehyde-fixed HUVECs & i.d & No & 3 & 0 & 0 & 0 \\
\hline$[54]$ & Xenogenic polyantigenic vaccine & S.C & $\mathrm{IL}-2$ & 37 & 2 & 10 & 11 \\
\hline$[55]$ & Oncolytic poxvirus JX-594 & PEIT & GM-CSF & 4 & 0 & 0 & 3 \\
\hline$[56]$ & MIDGE & S.C & d-SLIM & 10 & 2 & 1 & 2 \\
\hline [57] & ALVAC-p53 & i.v & ALVAC & 16 & 0 & 0 & 1 \\
\hline$[58]$ & ONYX-015 adevirus & i.v & No & 18 & 0 & 0 & 7 \\
\hline [59] & TNFa AutoVacclne & i.m & $\mathrm{AH}$ & 33 & 2 & 0 & 7 \\
\hline$[60]$ & $\mathrm{rF}-\mathrm{CEA}-\mathrm{TRICOM}$ & i.d & B7.1 & 11 & 0 & 1 & 4 \\
\hline [61] & CEA alt-plused DC & iv & No & 7 & 0 & 0 & 1 \\
\hline$[62]$ & DC-CEA peptid & i.t & IL-4/GM-CSF & 10 & 0 & 0 & 2 \\
\hline$[63]$ & Murine monoclonal CEA-antibody & i.d & $\mathrm{AH}$ & 15 & 0 & 0 & 1 \\
\hline$[64]$ & Ep-CAM protein & S.C & MPL/GM-CSF & 11 & 0 & 0 & 3 \\
\hline$[65]$ & Vaccine virus expressing CEA & i.d/s.c & No & 20 & 0 & 0 & 2 \\
\hline$[66]$ & DC + CEA peptide & i.v/i.d & $\mathrm{IL}-2$ & 11 & 0 & 0 & 0 \\
\hline$[67]$ & Antibody SCV 106 mimicking 17-1A & S.C & $\mathrm{AH}$ & 21 & 0 & 0 & 0 \\
\hline$[68]$ & Autologous tumor & S.C & Fibroblasts/IL-2 & 10 & 0 & 0 & 1 \\
\hline$[69]$ & retroviral vector- IL-2 allogeneic tumor cells + IL-1a & i.d & DETOX/IL-1a & 22 & 0 & 2 & 0 \\
\hline Total & 43 & & & 656 & $11(1.68 \%)$ & $19(2.9 \%)$ & 141( \\
\hline
\end{tabular}

Abbreviations: Ref, reference $\square$ AH: aluminum hydroxide; NI, not identifiable; NR, not Reported; DC, dendritic cells $\square$ NDV, newcastle disease virus; IL, interleukin; B-HCG, ß-human chorionic gonadotropin; THI,tetanustoxoidntigen/hepatitis B/influence matrix peptide; IFA, incompleteFreund's adjuvant.

$\mathrm{df}=5, \mathrm{P}=0.05, \mathrm{I} 2=55 \%$ ) (Figure 1 ), using the randomeffect method for meta-analysis. HR for ASI in stage I-IV suspected minimal residual CRC was 0.76 (95\% CI 0.630.93), the difference of OS at the end of follow-up between the ASI in stage I-IV suspected minimal residual CRC group and control groups was statistically significant $(\mathrm{Z}=2.68, \mathrm{P}=$ 0.007) (Figure 1).

For stage II or III suspected minimal residual CRC, There were no statistical heterogeneity (Heterogeneity for stage II: Chi $2=0.20$, df $=1, P=0.65, \mathrm{I} 2=0 \%$; for 


\begin{tabular}{|c|c|c|c|c|c|c|c|}
\hline \multirow[b]{2}{*}{ Stucty or Subqroup } & \multicolumn{2}{|c|}{ Experimental } & \multicolumn{2}{|c|}{ Control } & \multirow{2}{*}{ Weight } & \multirow{2}{*}{$\begin{array}{c}\text { Risk Ratio } \\
\text { N, Fixed, 95\% } \mathrm{Cl}\end{array}$} & \multirow{2}{*}{$\begin{array}{c}\text { Risk Ratio } \\
\text { N, Fixed, 95\% } \mathrm{Cl}\end{array}$} \\
\hline & Events & Total & Events & Total & & & \\
\hline Schulze T 2009 & 12 & 50 & 16 & 50 & $3.4 \%$ & $0.75[0.40,1.42]$ & $\longrightarrow+$ \\
\hline Uylde Groot CA 2005 & 30 & 124 & 33 & 117 & $7.7 \%$ & $0.86[0.56,1.31]$ & $\rightarrow$ \\
\hline Harris JE 2000 & 31 & 106 & 57 & 153 & $10.8 \%$ & $0.79[0.55,1.13]$ & $\rightarrow$ \\
\hline Tarasov VA 1999 & 20 & 42 & 48 & 50 & $13.5 \%$ & $0.50[0.36,0.68]$ & 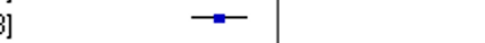 \\
\hline Riethmuller G 1998 & 39 & 90 & 48 & 117 & $13.6 \%$ & $1.06[0.77,1.46]$ & - \\
\hline Llang W 2003 & 135 & 310 & 146 & 257 & $51.0 \%$ & $0.77[0.65,0.90]$ & 둘 \\
\hline Total (95\% $\mathrm{Cl})$ & & 722 & & 744 & $100.0 \%$ & $0.76[0.68,0.86]$ & $\checkmark$ \\
\hline Total events & 267 & & 348 & & & & \\
\hline \multicolumn{7}{|c|}{$\begin{array}{l}\text { Heterogeneity: } \mathrm{Chi}^{2}=11.13, \mathrm{df}=5(\mathrm{P}=0.05) ;\left.\right|^{2}=55 \% \\
\text { Test for overall effect: } Z=4.48(P=0.00001)\end{array}$} & 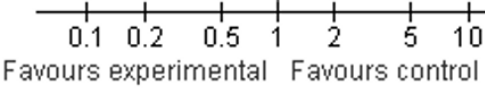 \\
\hline
\end{tabular}

stage III: Chi $2=2.69, \mathrm{df}=2, \mathrm{P}=0.26, \mathrm{I} 2=26 \%$ ) allowing the use of a fixed effect model for meta-analysis (Figure 2, 3). HR for stage II was 0.71 (95\% CI 0.48-1.06, $\mathrm{Z}=1.69, \mathrm{P}=0.09$ ) (Figure 2), and HR for stage III was 0.76 (95\% CI 0.61-0.96, $\mathrm{Z}=2.32, \mathrm{P}=0.02$ ) (Figure 3 ). For ASI in stage II suspected minimal residual CRC, OS approached significance $(\mathrm{P}=$ 0.09) when compared with control; however, the difference in OS of ASI for the stage III suspected minimal residual $\mathrm{CRC}$ reached statistical significance.

The DFS of the patients in three studies at the end follow-up is shown in table 1 . These included 666 patients and showed the HR for DFS in stage II and stage III suspected minimal residual CRC was 0.76 (95\% CI 0.59-0.97, $\mathrm{Z}=2.23, \mathrm{P}=0.03$ ) (Figure 4 ), which showed ASI in stage II and stage III suspected minimal residual CRC was markedly effective in term of DFS. No statistical heterogeneity was found (Chi2 $=0.00, \mathrm{df}=1, \mathrm{P}=0.99, \mathrm{I} 2=0 \%$ ) (Heterogeneity for stage II-III suspected minimal residual CRC: Chi2 $=0.00, \mathrm{df}=1, \mathrm{P}=0.99, \mathrm{I} 2=0 \%$; for stage II Chi2 $=0.74, \mathrm{df}=1, \mathrm{P}=0.39, \mathrm{I} 2=0 \%$; for stage III: Chi2 $=1.67, \mathrm{df}=2, \mathrm{P}=0.43, \mathrm{I} 2=0 \%$ ) (Figure 4, 5, 6), allowing the use of a fixed effect model for meta-analysis. The HR for DFS in stage II suspected minimal residual CRC was 0.66 (95\% CI 0.47-0.94, $\mathrm{Z}=2.29, \mathrm{P}=0.02$ ) (Figure 5), compared to a $0.81 \mathrm{HR}$ in stage III suspected minimal residual CRC (95\% CI 0.67-0.97, $\mathrm{Z}=2.22, \mathrm{P}=0.03$ ) (Figure 6). The results revealed that ASI in stage II suspected minimal residual CRC was more effective than in stage III suspected minimal residual CRC in term of DFS.

\section{Assessment of ASI in advanced CRC}

For analysis of ASI in advanced CRC, 656 patients were evaluated for clinical responses. Eleven patients reported $\mathrm{CR}$ and seventeen reported $\mathrm{PR}$, out of a total population of 656 patients, which corresponded to an overall response rate of $1.68 \%$. MR was reported in $2.90 \%$ of patients; SD was found in $21.49 \%$. The combined percentages of CR, PR, MR, and SD for all patients yielded a CBR of $26.07 \%$ (Table 2).

In 43 studies of ASI in advance CRC, patients received a variety of vaccinations including dendritic cells in fourteen studies, viral vector vaccines in ten, peptide in eight, autologous or allogeneic tumor cells or tumorderived products in five, monoclonal antibodies and anti-idiotype vaccines in four, and other substances in five studies (naked DNA vaccine, define-tumor protein vaccine, autologous hemoderivative cyclophosphamide, glutaraldehyde-fixed HUVECs and xenogenic polyantigenic vaccine). CBR of 45/142 (31.7\%) for multi-peptide vaccines, $17 / 70(28.6 \%)$ for autologous tumor cell vaccine, 46/163 (28.2\%) for viral vector vaccine, 30/134 (22.4\%) for dendritic cell-based vaccines (Table 3 ).

Despite the broad variety of antigens described, carcinoembryonic antigen-based vaccination was used in 18

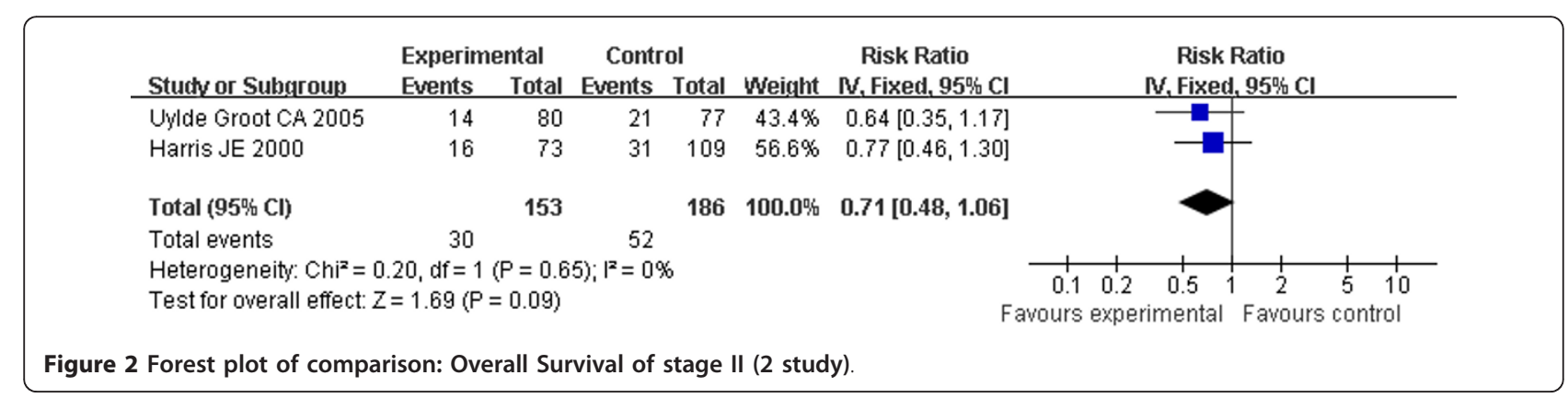




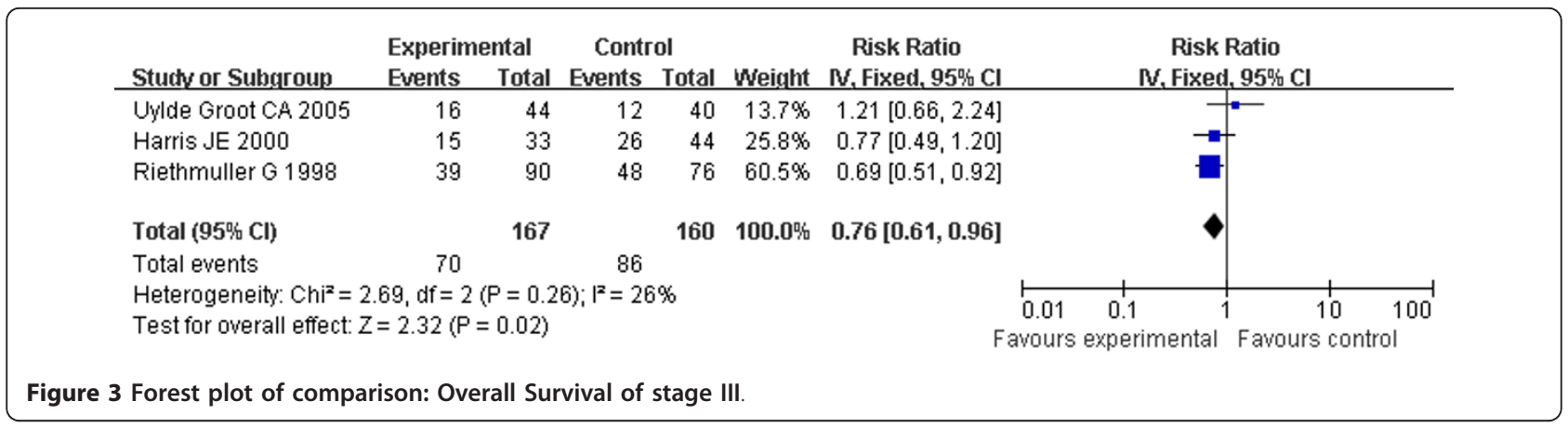

studies included in the present review. 1 PR, 2 MR, and 49 SD were reported in a total population of 256 patients $(C B R=20.3 \%)$. Fifteen further substances were used as adjuvants, Ten studies were done without adjuvants. Vaccines were administrated by different routes of injection: $\mathrm{s}$. c. in ten studies, i.d. eight studies, i.m. five studies, i.v. four studies, i.d. and s.c. five studies, i.v. and i.d. three studies, and intralymphatic/intranodal two studies. In a post hoc analysis, The CBR ranged between $19.7 \%$ and $34 \%$ regardless of the route of vaccination (Table 4).

\section{Assessment of Toxicity for ASI in CRC}

The current clinical experience with ASI does not indicate considerable toxicity. Neither short-term serious adverse events nor long-term autoimmune side effects have been observed using therapeutic vaccines in a large number of patients. The most frequently reported adverse events causally related to the use of ASI were mild (grade 1-2) in severity, including injection site reactions (e.g, erythema, pruritus, pain), fever, nausea, and fatigue. There were no significant hepatic, renal, pulmonary, cardiac, hematologic, or neurologic toxicities attributable to the treatments. No clinical manifestations of autoimmune reactions were observed. No significant changes in temperature and blood pressure were recorded. Other side effects include rare cases of adenopathy, diarrhea, rigors, malaise, and transfusion-like reactions. All other symptoms were described only in single cases and/or are most probably due to the advanced malignant disease or a side effect of adjuvants.

\section{Discussion}

According to our Meta-analysis, all patients with suspected minimal residual CRC who met quality control specifications and protocol eligibility (analyzable patients), OS $(\mathrm{P}=0.007)$, and DFS $(\mathrm{P}=0.003)$ were significantly improved when compared with controls. A subgroup analysis by stage of disease, For ASI in stage II suspected minimal residual CRC compared with control, OS approached significance when compared with control $(P=0.09)$, The DFS of ASI reached statistical significance $(\mathrm{P}=0.02)$; For ASI in stage III suspected minimal residual CRC compared with control, The difference in both OS $(\mathrm{P}=0.02)$ and DFS $(\mathrm{P}=0.03)$ achieved statistical significance. These results indicated ASI may provide a new promising targeted therapeutic approach in suspected minimal residual CRC.

The efficacy of ASI in patients with suspected minimal residual CRC is encouraging and merit generalization in colorectal cancer therapy based on three reasons. First, in less than a decade, because of improved diagnostic methods, there has been a major shift from stage IV to stage II CRC. In 1995, stage IV disease accounted for approximately $50 \%$ to $55 \%$ of all cases, stage III accounted for $30 \%$, and stage II for less than $20 \%$. For the year 2004, it is estimated that stage IV cancers will account for approximately $10 \%$ of all cases, while stage II disease will rise to $40 \%$ of all cases [65]. This progression is expected to continue through the rest of the decade, which means more and more CRC patients would procure benefits with ASI. Second, micro metastases are

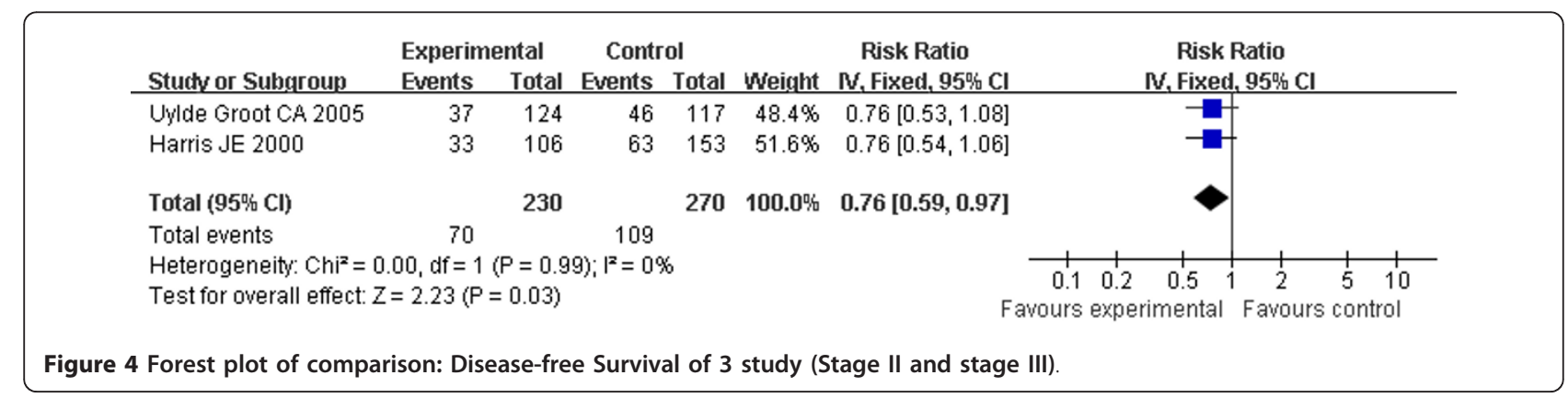




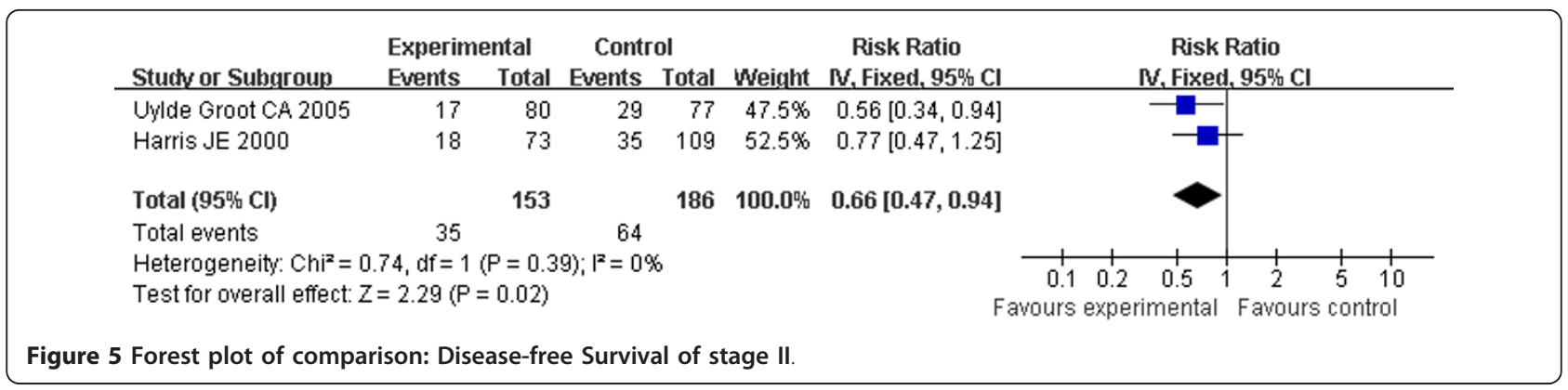

generally responsible for disease recurrence and the eventual death of CRC patients. Occult micro metastases or suspected minimal residual CRC have been detected in lymph nodes or in the operating field in $54 \%$ of stage II patients. Analysis of the relationship between PCR-detectable metastases and survival has resulted in an adjusted five year survival of $91 \%$ in patients without minimal residual CRC and 50\% in patients with minimal residual CRC, with observed five year survival rates of $75 \%$ and $36 \%$, respectively [66]. Hence, the development of new methods of treatment to eliminate micro metastases in patients with suspected minimal residual CRC and thereby delay or prevent recurrence is particularly urgent given the increasing incidence of CRC. Third, cancer stem cells may be responsible for tumor recurrence and metastatic lesions, and have been postulated to be a very small population of quiescent or very slowly dividing cells within a growing tumor mass. Such cells would be inherently resistant to treatments such as chemotherapy, which target proliferating cells [67]. Since the proliferation is not a prerequisite for recognition and destruction by the immune mechanisms, ASI may be the most effective way to eliminate cancer stem cells, ASI is likely to be applied in the setting of curatively minimal residual cancer with the goal of clearing the invisible but present cancer burden.

The efficacy of ASI in patients with advanced CRC was disappointed. Nagorsen et al evaluated the outcomes of ASI in advanced CRC from January 1985 to January 2006, which revealed a very weak clinical response rate of $0.9 \%$ for ASI procedures available for advanced CRC [13]. In the present system review, we found an objective response rate of $1.68 \%$ over 656 advanced CRC patients treated with ASI in 43 different studies. Peptide vaccination had the highest CBR of $31.7 \%$, followed by $28.6 \%$ for autologous tumor vaccines, $28.2 \%$ for viral vector vaccine, and $24.4 \%$ for DC-based therapy. These data are two-fold higher than those reported by Nagorsen et al. Our study has demonstrated that ASI in CRC has made recent progression.

However, although progression was conspicuous with ASI in advanced CRC, the clinical results are still limited. As new generations of vaccines are developed to improve the clinical efficiency, several considerations will require attention. First, because chemotherapy is standard in the treatment of CRC, it is important to demonstrate whether immunizations may be given to patients who are receiving systemic chemotherapy. This opportunity rests in strategically combining immunotherapies with both traditional and novel cancer drugs to shape both the global host environment and the local tumor environment, and to ameliorate distinct layers of immune tolerance, ultimately supporting a vigorous and sustained antitumor immune response [68]. Within this modified host environment, ASI regimens that (1) combine tumor vaccines or tumor-specific lymphocytes with targeted drugs that amplify the magnitude and quality of end immune effectors and (2) relieve the normal controls at specific points in the process of $\mathrm{T}$ cell activation will be critical for success [69]. More importantly, chemotherapeutic drugs kill

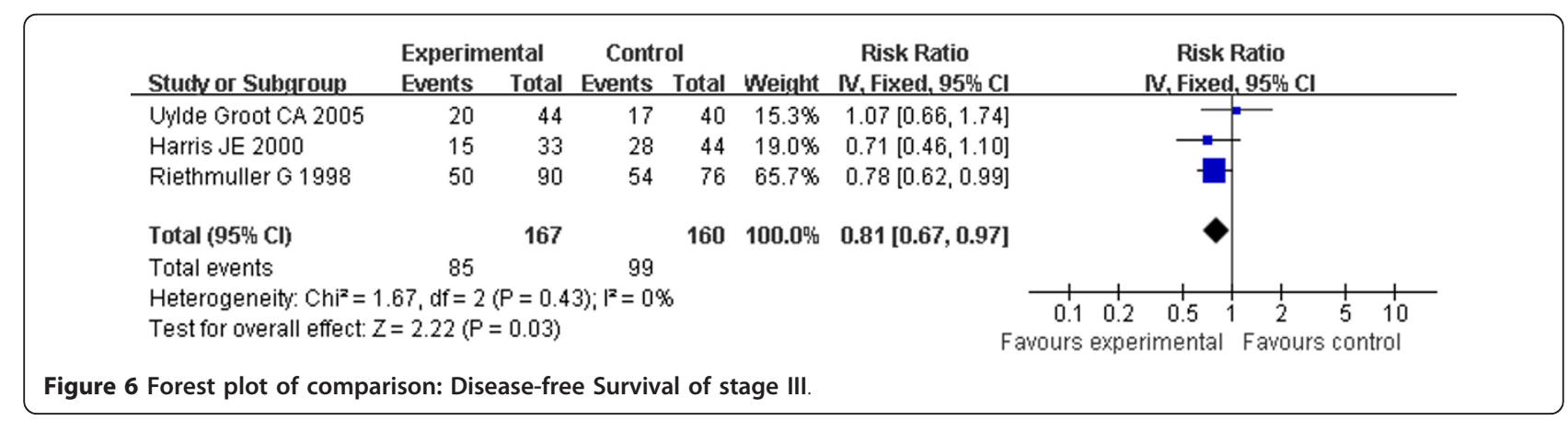


Table 3 Clinical benefit rate of ASI with diffident type of vaccines in advanced CRC, post hoc explorative analysis

\begin{tabular}{cc}
\hline vaccine & clinical benefit rate \\
\hline autologous tumor cell & $20 / 70(28.6 \%)$ \\
\hline Peptide vaccine & $45 / 142(31.7 \%)$ \\
\hline Viral vector vaccine & $46 / 163(28.2 \%)$ \\
\hline DC vaccine & $30 / 134(22.4 \%)$
\end{tabular}

tumor cells and, in the process, increase the amount of tumor antigens that are presented to immune system. Moreover, the process of apoptotic cell death may in itself provide an immunostimulatory signal. Both have the capacity to enhance antitumor immune responses. Second, ASI effectiveness depends on tumor burden. An advanced cancer actually induces Tregs and then uses them to subvert the immune response of ASI [70]. The implication is that the Tregs contribute to the inability of immune system to eliminate the growing tumor. It is thus apparent that effective ASI should include approaches that target Tregs in vivo. Several strategies have been employed with certain efficacy in cancer, including depletion with anti-CD25 antibodies, treatment with anti-GITR and anti-CTLA-4 [71-73]. The findings suggest depletion Tregs may be used in the future to improve immunotherapy in CRC [74]. Third, it may be more important to choose antigens that have functions important to the cancer cell. Some researchers have argued that immunologically targeting proteins without a known protumorigenic function may ultimately fail because tumors could down-regulate these antigens without a detrimental effect to their function [75]. As new generations of vaccines are developed, DNA vaccination is a promising avenue for the development of a successful CRC vaccine [76]. However, there is only one clinical trial which utilizes a DNA vaccine for CRC [22]. We agree with those who find it premature to give up on active cancer vaccines, although much work remains.

\section{Conclusions}

In summary, This Meta-analysis and System Review clearly supports the idea that a statistically significantly improved DFS or OS was shown in all stage suspected minimal residual CRC patients. Meanwhile, there was also a clear indication that the objective clinical outcome

$\begin{aligned} & \text { Table } \mathbf{4} \text { Influence of vaccination route, post hoc } \\
& \text { explorative analysis }\end{aligned}$
\begin{tabular}{ll}
\hline vaccine & clinical benefit rate \\
\hline s.c & $73 / 215(34.0 \%)$ \\
i.m & $16 / 80(20.0 \%)$ \\
i.d & $31 / 120(25.0 \%)$ \\
i.v & $15 / 76(19.7 \%)$ \\
\hline
\end{tabular}

of ASI in advanced CRC was only $1.6 \%$. The results showed it is unlikely that ASI will provide a standard complementary therapeutic approach for advanced CRC in the near future. However, it has become clear that immunotherapy works best in situations of patients with suspected minimal residual CRC.

\section{Acknowledgements}

This study was supported by the Doctor Dot Research Program of China (No.200805580074). We thank Junxiao Zhang for his expert suggestions and constructive comments on this manuscript. We also thank Dr. Joanne Nicholas Klemen for offering English language editorial assistance.

\section{Author details}

${ }^{1}$ Colorectal Surgery Department, The Sixth Affiliated Hospital, Sun Yat-sen University, Guangdong 510655, PR China. ${ }^{2}$ Medical Department, The Sixth Affiliated Hospital, Sun Yat-sen University, Guangdong 510655,PR China. ${ }^{3}$ Department of Pediatrics, The Sixth Affiliated Hospital, Sun Yat-sen University, Guangdong 510655, PR China. ${ }^{4}$ Institute of Gastroenterology, Sun Yat-sen University, Guangzhou, Guangdong 510655, PR China.

\section{Authors' contributions}

JW conceived the study, provided funding support, and revised the manuscript critically for important intellectual content. BR made substantial contributions to the design, acquisition, analysis, and interpretation of data. $\mathrm{MH}, \mathrm{LW}, \mathrm{MH}, \mathrm{XG}, \mathrm{HL}$ and $\mathrm{JH}$ participated in the design, acquisition, analysis and interpretation of data. All authors approved the final manuscript.

\section{Competing interests}

The authors declare that they have no competing interests.

Received: 30 April 2010 Accepted: 27 January 2011

Published: 27 January 2011

\section{References}

1. Parkin DM, Bray F, Ferlay J, Pisani P: Global cancer statistics, 2002. CA Cancer J Clin 2005, 55:74-108.

2. Kerr D: Clinical development of gene therapy for colorectal cancer. Nat Rev Cancer 2003, 3:615-622

3. Lorenz M, Staib-Sebler E, Hochmuth K, Heinrich S, Gog C, Vetter G, Encke A, Muller $\mathrm{HH}$ : Surgical resection of liver metastases of colorectal carcinoma: short and long-term results. Semin Oncol 2000, 27:112-119.

4. Weitz J, Koch M, Debus J, Höhler T, Galle PR, Büchler MW: Colorectal cancer. Lancet 2005, 365:153-165.

5. Tebbutt NC, Cattell E, Midgley R, Cunningham D, Kerr D: Systemic treatment of colorectal cancer. Eur J Cancer 2002, 38:1000-1015.

6. SEER Cancer Statistics Review, 1975-2003. National Cancer Institute, retrieved; 2006 [http://seer.cancer.gov/csr/1975-2003/].

7. Smith RE, Colangelo L, Wieand HS, Begovic M, Wolmark N: Randomized trial of adjuvant therapy in colon carcinoma: 10-year results of NSABP protocol C-01. J Natl Cancer Inst 2004, 96:1128-1132.

8. Ohwada S, Ikeya T, Yokomori T, Kusaba T, Roppongi T, Takahashi T, Nakamura S, Kakinuma S, Iwazaki S, Ishikawa H, Kawate S, Nakajima T, Morishita Y: Adjuvant immunochemotherapy with oral Tegafur/Uracil plus PSK in patients with stage II or III colorectal cancer: a randomised controlled study. Br J Cancer 2004, 90:1003-1010.

9. Wolmark N, Bryant J, Smith R, Grem J, Allegra C, Hyams D, Atkins J, Dimitrov N, Oishi R, Prager D, Fehrenbacher L, Romond E, Colangelo L, Fisher B: Adjuvant 5-uorouracil and leucovorin with or without interferon alfa-2a in colon carcinoma: National Surgical Adjuvant Breast and Bowel Project protocol C-05. J Natl Cancer Inst 1998, 90:1810-1816.

10. Morse M, Langer L, Starodub A, Hobeika A, Clay T, Lyerly HK: Current Immunotherapeutic Strategies in Colon Cancer. Surg Oncol Clin N Am 2007, 16:873-900.

11. Mocellin S, Mandruzzato S, Bronte V, Marincola FM: Cancer vaccines: pessimism in check. Nat Med 2004, 10:1278-1279.

12. Rosenberg SA, Yang JC, Restifo NP: Cancer immunotherapy: moving beyond current vaccines. Nat Med 2004, 10:909-915. 
13. Nagorsen D, Thiel E: Clinical and Immunologic Responses to Active Specific Cancer Vaccines in Human Colorectal Cancer. Clin Cancer Res 2006, 12:3064-3069.

14. Alejandro R, Jadad MD, DPhil R, Andrew Moore DPhil, Dawn Carroll RGN, Crispin Jenkinson DPhil D, John M, Reynolds DPhil, David J, Gavaghan DPhil, Henry J, McQuay DM: Assessing the quality of reports of randomized clinical t rials: Is blinding necessary ? Control Clinic Trials 1996, 17:1-12.

15. Higgins JP, Thompson SG: Quantifying heterogeneity in a meta-analysis. Stat Med 2002, 21:1539-1558.

16. Harris JE, Ryan L, Hoover HC Jr, Stuart RK, Oken MM, Benson AB, Mansour E, Haller DG, Manola J, Hanna MG Jr: Adjuvant Active Specific Immunotherapy for Stage II and III Colon Cancer With an Autologous Tumor Cell Vaccine: Eastern Cooperative Oncology Group Study E5283. J Clin Oncol 2000, 18:148-153.

17. Uyl-de Groot CA, Vermorken JB, Hanna MG Jr, Verboom P, Groot MT, Bonsel GJ, Meijer CJ, Pinedo HM: Immunotherapy with autologous tumor cell-BCG vaccine in patients with colon cancer: a prospective study of medical and economic benets. Vaccine 2005, 23:2379-2387.

18. Schulze T, Kemmner W, Weitz J, Wernecke KD, Schirrmacher V, Schlag PM: Efficiency of adjuvant active specific immunization with Newcastle disease virus modified tumor cells in colorectal cancer patients following resection of liver metastases: results of a prospective randomized trial. Cancer Immunol Immunother 2009, 58:61-69.

19. Riethmüller G, Holz E, Schlimok G, Schmiegel W, Raab R, Höffken K Gruber R, Funke I, Pichlmaier H, Hirche H, Buggisch P, Witte J, Pichlmayr R: Monoclonal Antibody Therapy for Resected Dukes' Colorectal Cancer: Seven-Year Outcome of a Multicenter Randomized Trial. J Clin Oncol 1998, 16:1788-1794.

20. Liang $W$, Wang $H$, Sun $T M$, Yao $W Q$, Chen $L L$, Jin $Y$, Li CL, Meng FJ, et al: Application of autologous tumor cell vaccine and NDV vaccine in treatment of tumors of digestive traet. World J Gastroenterol 2003, 9:495-498

21. Tarasov VA, Filatov MV, Kisliakova TV, Noskov FS, Koloskov AV, Stavrovietski W, Onikienko SB, Kletchikov VZ, Lvov IV, Yu Varfolomeeva E, Blizniukov OP, Levina W, Kiselevski MV: Combined Surgical and Immunotherapeutic Treatment of Patients with Fourth Stage Colon Cancer. Hybridoma 1999, 18:99-102.

22. Bhattachary-Chatterjee M, Nath Baral R, Chatterjee SK, Das R, Zeytin H, Chakraborty M, Foon KA: Counterpoint. Cancer vaccines: single-epitope anti-idiotype vaccine versus multiple- epitope antigen vaccine. Cancer Immunol Immunother 2000, 49:133-141.

23. Conry RM, Curiel DT, Strong TV, Moore SE, Allen KO, Barlow DL, Shaw DR LoBuglio AF: Safety and Immunogenicity of a DNA Vaccine Encoding Carcinoembryonic Antigen and Hepatitis B Surface Antigen in Colorectal Carcinoma Patients. Clin Cancer Res 2002, 8:2782-2787.

24. Fong L, Hou Y, Rivas A, Benike C, Yuen A, Fisher GA, Davis MM, Engleman EG: Altered peptide ligand vaccination with Flt3 ligand expanded dendritic cells for tumor immunotherapy. Proc Natl Acad Sci USA 2001, 98:8809-8814

25. Hörig H, Lee DS, Conkright W, Divito J, Hasson H, LaMare M, Rivera A, Park D, Tine J, Guito K, Tsang KW, Schlom J, Kaufman HL: Phase I clinical trial of a recombinant canarypoxvirus (ALVAC) vaccine expressing human carcinoembryonic antigen and the B7.1 co-stimulatory molecule. Cancer Immunol Immunother 2000, 49:504-514.

26. Itoh T, Ueda Y, Kawashima I, Nukaya I, Fujiwara H, Fuji N, Yamashita T, Yoshimura T, Okugawa K, Iwasaki T, Ideno M, Takesako K, Mitsuhashi M, Orita K, Yamagishi H: Immunotherapy of solid cancer using dendritic cells pulsed with the HLA-A24-restricted peptide of carcinoembryonic antigen. Cancer Immunol Immunother 2002, 51:99-106.

27. Liang W, Wang $H$, Sun $T M$, Yao WQ, Chen LL, Jin Y, Li CL, Meng FJ: Application of autologous tumor cell vaccine and NDV vaccine in treatment of tumors of digestive tract. World I Gastroenterol 2003, 9:495-498

28. Liu KJ, Wang CC, Chen LT, Cheng AL, Lin DT, Wu YC, Yu WL, Hung YM, Yang HY, Juang SH, Whang-Peng J: Generation of carcinoembryonic antigen (CEA)-specific T-cell responses in HLA-A*0201 and HLA-A*2402 late-stage colorectal cancer patients after vaccination with dendritic cells loaded with CEA peptides. Clin Cancer Res 2004, 10:2645-2651.

29. Marshall JL, Hoyer RJ, Toomey MA, Faraguna K, Chang P, Richmond E, Pedicano JE, Gehan E, Peck RA, Arlen P, Tsang KY, Schlom J: Phase I study in advanced cancer patients of a diversified prime-and-boost vaccination protocol using recombinant vaccinia virus and recombinant nonreplicating avipox virus to elicit anti-carcinoembryonic antigen immune responses. J Clin Onco 2000, 18:3964-3973.

30. Marshall JL, Gulley JL, Arlen PM, Beetham PK, Tsang KY, Slack R, Hodge JW Doren S, Grosenbach DW, Hwang J, Fox E, Odogwu L, Park S, Panicali D, Schlom J: Phase I study of sequential vaccinations with fowlpox-CEA (6D)-TRICOM alone and sequentially with vaccinia-CEA(6D)-TRICOM, with and without granulocyte-macrophage colony-stimulating factor, in patients with carcinoembryonic antigen-expressing carcinomas. I Clin Oncol 2005, 23:720-731.

31. Matsuda K, Tsunoda T, Tanaka H, Umano Y, Tanimura H, Nukaya I, Takesako K, Yamaue H: Enhancement of cytotoxic T-lymphocyte responses in patients with gastrointestinal malignancies following vaccination with CEA peptide-pulsed dendritic cells. Cancer Immunol Immunother 2004, 53:609-616.

32. Miyagi $Y$, Imai N, Sasatomi T, Yamada A, Mine T, Katagiri K, Nakagawa M Muto A, Okouchi S, Isomoto H, Shirouzu K, Yamana H, Itoh K: Induction of cellular immune responses to tumor cells and peptides in colorectal cancer patients by vaccination with SART3 peptides. Clin Cancer Res 2001, 7:3950-3962.

33. Morse MA, Nair SK, Mosca PJ, Hobeika AC, Clay TM, Deng Y, Boczkowski D, Proia A, Neidzwiecki D, Clavien PA, Hurwitz HI, Schlom J, Gilboa E, Lyerly HK: Immunotherapy with autologous, human dendritic cells transfected with carcinoembryonic antigen mRNA. Cancer Invest 2003, 21:341-349.

34. Morse MA, Clay TM, Hobeika AC, Osada T, Khan S, Chui S, Niedzwiecki D, Panicali D, Schlom J, Lyerly HK: Phase I study of immunization with dendritic cells modified with fowlpox encoding carcinoembryonic antigen and costimulatory molecules. Clin Cancer Res 2005, 11:3017-3024.

35. Rains N, Cannan RJ, Chen W, Stubbs RS: Development of a dendritic cell (DC)-based vaccine for patients with advanced colorectal cancer. Hepatogastroenterology 2001, 48:347-351.

36. Sadanaga N, Nagashima H, Mashino K, Tahara K, Yamaguchi H, Ohta M Fujie T, Tanaka F, Inoue H, Takesako K, Akiyoshi T, Mori M: Dendritic cell vaccination with MAGE peptide is a novel therapeutic approach for gastrointestinal carcinomas. Clin Cancer Res 2001, 7:2277-2284.

37. Sato Y, Maeda Y, Shomura H, Sasatomi T, Takahashi M, Une Y, Kondo M, Shinohara T, Hida N, Katagiri K, Sato K, Sato M, Yamada A, Yamana H, Harada M, Itoh K, Todo S: A phase I trial of cytotoxic T- lymphocyte precursor-oriented peptide vaccines for colorectal carcinoma patients. $\mathrm{Br}$ J Cancer 2004, 90:1334-1342.

38. Tsuruma T, Hata F, Torigoe $T$, Furuhata $T$, Idenoue $S$, Kurotaki T, Yamamoto M, Yagihashi A, Ohmura T, Yamaguchi K, Katsuramaki T, Yasoshima T, Sasaki K, Mizushima Y, Minamida H, Kimura H, Akiyama M, Hirohashi Y, Asanuma H, Tamura Y, Shimozawa K, Sato N, Hirata K: Phase I clinical study of anti-apoptosis protein, survivin-derived peptide vaccine therapy for patients with advanced or recurrent colorectal cancer. Transl Med 2004, 2:19-24.

39. Ueda Y, Itoh T, Nukaya I, Kawashima I, Okugawa K, Yano Y, Yamamoto Y, Naitoh K, Shimizu K, Imura K, Fuji N, Fujiwara H, Ochiai T, Itoi H, Sonoyama T, Hagiwara A, Takesako K, Yamagishi H: Dendritic cell-based immunotherapy of cancer with carcinoembryonic antigen-derived, HLA A24-restricted CTL epitope: clinical outcomes of 18 patients with metastatic gastrointestinal or lung adenocarcinomas. Int J Oncol 2004, 24:909-917.

40. von Mehren M, Arlen P, Tsang KY, Rogatko A, Meropol N, Cooper HS, Davey M, McLaughlin S, Schlom J, Weiner LM: Pilot study of a dual gene recombinant avipox vaccine containing both carcinoembryonic antigen (CEA) and B7.1 transgenes in patients with recurrent CEA-expressing adenocarcinomas. Clin Cancer Res 2000, 6:2219-2228.

41. Lasalvia-Prisco E, Garcia-Giralt E, Cucchi S, Vázquez J, Lasalvia-Galante E, Golomar W, Larrañga J: Advanced Colon Cancer: Antiprogressive Immunotherapy Using an Autologous Hemoderivative. Med Oncol 2006, 23:91-104

42. Burgdorf SK, Fischer A, Myschetzky PS, Munksgaard SB, Zocca MB, Claesson MH, Rosenberg J: Clinical responses in patients with advanced colorectal cancer to a dendritic cell based vaccine. oncol Rep 2008, 20:1305-1311.

43. Harrop R, Connolly N, Redchenko I, Valle J, Saunders M, Ryan MG, Myers KA Drury N, Kingsman SM, Hawkins RE, Carroll MW: Vaccination of Colorectal 
Cancer Patients with Modified Vaccinia Ankara Delivering the Tumor Antigen 5T4 (TroVax) Induces Immune Responses which Correlate with Disease Control: A Phase I/II Trial. Clin Cancer Res 2006, 12:3416-3424.

44. Speetjens FM, Kuppen PJ, Welters MJ, Essahsah F, Voet van den Brink AM Lantrua MG, Valentijn AR, Oostendorp J, Fathers LM, Nijman HW, Drijfhout JW, van de Velde CJ, van der Melief CJ: Induction of p53-Specific Immunity by a p53 Synthetic Long Peptide Vaccine in Patients Treated for Metastatic Colorectal Cancer. Clin Cancer Res 2009, 15:1086-1091.

45. Tamir A, Basagila E, Kagahzian A, Jiao L, Jensen S, Nicholls J, Tate $P$, Stamp G, Farzaneh F, Harrison P, Stauss H, George AJ, Habib N, Lechler RI, Lombardi G: Induction of tumor-specific T-cell responses by vaccination with tumor lysate-loaded dendritic cells in colorectal cancer patients with carcinoembryonic-antigen positive tumors. Cancer Immunol Immunother 2007, 56:2003-2016.

46. Dai S, Wei D, Wu Z, Zhou X, Wei X, Huang H, Li G: Phase I Clinical Trial of Autologous Ascites-derived Exosomes Combined With GM-CSF for Colorectal Cancer. Mol Ther 2008, 164:782-790.

47. Kavanagh B, Ko A, Venook A, Margolin K, Zeh H, Lotze M, Schillinger B, Liu W, Lu Y, Mitsky P, Schilling M, Bercovici N, Loudovaris M, Guillermo R, Lee SM, Bender J, Mills B, Fong L: Vaccination of Metastatic Colorectal Cancer Patients With Matured Dendritic Cells Loaded With Multiple Major Histocompatibility Complex Class I Peptides. I Immunother 2007, 30:762-772.

48. Okaji Y, Tsuno NH, Tanaka M, Yoneyama S, Matsuhashi M, Kitayama J, Saito S, Nagura Y, Tsuchiya T, Yamada J, Tanaka J, Yoshikawa N, Nishikawa T, Shuno Y, Todo T, Saito N, Takahashi K: Pilot study of antiangiogenic vaccine using fixed whole endothelium in patients with progressive malignancy after failure of conventional therapy. Eur $J$ Cancer 2008, 44:383-390.

49. Seledtsov VI, Niza NA, Felde MA, Shishkov AA, Samarin DM, Seledtsova GV, Seledtsov DV: Xenovaccinotherapy for colorectal cancer. Biomed Pharmacother 2007, 61:125-130

50. Park BH, Hwang T, Liu TC, Sze DY, Kim JS, Kwon HC, Oh SY, Han SY, Yoon JH, Hong SH, Moon A, Speth K, Park C, Ahn YJ, Daneshmand M, Rhee BG, Pinedo HM, Bell JC, Kirn DH: Use of a targeted oncolytic poxvirus, JX-594, in patients with refractory primary or metastatic liver cancer: a phase I trial. Lancet Oncol 2008, 9:533-542.

51. Wittig B, Märten A, Dorbic T, Weineck S, Min H, Niemitz S, Trojaneck B, Flieger D, Kruopis S, Albers A, Löffel J, Neubauer A, Albers P, Müller S, Sauerbruch T, Bieber T, Huhn D, Schmidt-Wolf IG: Therapeutic Vaccination against Metastatic Carcinoma by Expression-Modulated and Immunomodified Autologous Tumor Cells: A First Clinical Phase I/II Trial. Hum Gene Ther 2001, 12:267-278.

52. Menon AG, Kuppen PJ, van der Burg SH, Offringa R, Bonnet MC, Harinck Bl, Tollenaar RA, Redeker A, Putter H, Moingeon P, Morreau H, Melief CJ, van de Velde CJ: Safety of intravenous administration of a canarypox virus encoding the human wild-type $\mathrm{p} 53$ gene in colorectal cancer patients. Cancer Gene Ther 2003, 10:509-517.

53. Hamid O, Varterasian ML, Wadler S, Hecht JR, Benson A, Galanis E, Uprichard M, Omer C, Bycott P, Hackman RC, Shields AF: Phase II Trial of Intravenous Cl-1042 in Patients With Metastatic Colorectal Cancer. J Clin Oncol 2003, 21:1498-1504.

54. Waterston AM, Gumbrell L, Bratt T, Waller S, Gustav-Aspland J, L'hermenier C, Bellenger K, Campbell M, Powles T, Highley M, Bower M, Mouritsen S, Feldmann M, Coombes RC: Phase I study of TNFalpha AutoVacclne in patients with metastatic cancer. Cancer Immunol Immunother 2005, 54:848-857.

55. Morse MA, Clay TM, Hobeika AC, Osada T, Khan S, Chui S, Niedzwiecki D, Panicali D, Schlom J, Lyerly HK: Phase I Study of Immunization with Dendritic Cells Modified with Fowlpox Encoding Carcinoembryonic Antigen and Costimulatory Molecules. Clin Cancer Res 2005, 11:3017-3024.

56. Babatz J, Röllig C, Löbel B, Folprecht $G$, Haack M, Günther $H$, Köhne $C H$, Ehninger G, Schmitz M, Bornhäuser M: Induction of cellular immune responses against carcinoembryonic antigen in patients with metastatic tumors after vaccination with altered peptide ligand-loaded dendritic cells. Cancer Immunol Immunother 2006, 55:268-276.

57. Liu KJ, Wang CC, Chen LT, Cheng AL, Lin DT, Wu YC, Yu WL, Hung YM, Yang HY, Juang SH, Whang-Peng J: Generation of carcinoembryonic antigen (CEA)-specific T-cell responses in HLA-A*0201 and HLA-A 2402 late-stage colorectal cancer patients after vaccination with dendritic cells loaded with CEA peptides. Clin Cancer Res 2004, 10:2645-2651.
58. Zbar AP, Thomas H, Wilkinson RW, Wadhwa M, Syrigos KN, Ross EL, Dilger P, Allen-Mersh TG, Kmiot WA, Epenetos AA, Snary D, Bodmer WF: Immune responses in advanced colorectal cancer following repeated intradermal vaccination with the anti-CEA murine monoclonal antibody, PR1A3: results of a phase I study. Int I Colorectal Dis 2005, 20:403-414.

59. Neidhart J, Allen KO, Barlow DL, Carpenter M, Shaw DR, Triozzi PL, Conry RM: Immunization of colorectal cancer patients with recombinant baculovirus-derived KSA (Ep-CAM) formulated with monophosphoryl lipid $A$ in liposomal emulsion, with and without granulocytemacrophage colony-stimulating factor. Vaccine 2004, 22:773-780

60. Conry RM, Khazaeli MB, Saleh MN, Allen KO, Barlow DL, Moore SE, Craig D, Arani RB, Schlom J, LoBuglio AF: Phase I trial of a recombinant vaccinia virus encoding carcinoembryonic antigen in metastatic adenocarcinoma: comparison of intradermal versus subcutaneous administration. Clin Cancer Res 1999, 5:2330-2337.

61. Morse MA, Deng Y, Coleman D, Hull S, Kitrell-Fisher E, Nair S, Schlom J, Ryback ME, Lyerly HK: A Phase I study of active immunotherapy with carcinoembryonic antigen peptide (CAP-1)-pulsed, autologous human cultured dendritic cells in patients with metastatic malignancies expressing carcinoembryonic antigen. Clin Cancer Res 1999, 5:1331-1338.

62. Samonigg H, Wilders-Truschnig M, Kuss I, Plot R, Stöger H, Schmid M, Bauernhofer T, Tiran A, Pieber T, Havelec L, Loibner H: A double-blind randomized-phase II trial comparing immunization with antiidiotype goat antibody vaccine SCV 106 versus unspecific goat antibodies in patients with metastatic colorectal cancer. J Immunother 1999, 22:481-488.

63. Sobol RE, Shawler DL, Carson C, Van Beveren C, Mercola D, Fakhrai H, Garrett MA, Barone R, Goldfarb P, Bartholomew RM, Brostoff S, Carlo DJ, Royston I, Gold DP: Interleukin 2 gene therapy of colorectal carcinoma with autologous irradiated tumor cells and genetically engineered fibroblasts: a Phase I study. Clin Cancer Res 1999, 5:2359-2365.

64. Woodlock TJ, Sahasrabudhe DM, Marquis DM, Greene D, Pandya K, McCune CS: Active specific immunotherapy for metastatic colorectal carcinoma: phase I study of an allogeneic cell vaccine plus low-dose interleukin-1 alpha. J Immuno ther 1999, 22:251-259.

65. Hanna MG Jr, Hoover HC Jr, Pinedo HM, Finer M: Active Specific Immunotherapy with Autologous Tumor Cell Vaccines for Stage II Colon Cancer: Logistics, Efficacy, Safety and Immunological Pharmacodynamics. Hum Vaccin 2006, 2:185-191.

66. Liefers GJ, Cleton-Jansen AM, van de Velde CJ, Hermans J, van Krieken JH, Cornelisse CJ, Tollenaar RA: Micrometastases and survival in stage II colorectal cancer. N Engl J Med 1998, 339:223-228.

67. O'Brien CA, Pollett A, Gallinger S, Dick JE: A human colon cancer cell capable of initiating tumour growth in immunodeficient mice. Nature 2007, 445:106-110

68. von Mehren M, Arlen P, Gulley J, Rogatko A, Cooper HS, Meropol NJ, Alpaugh RK, Davey M, McLaughlin S, Beard MT, Tsang KY, Schlom J, Weiner LM: The influence of granulocyte macrophage colony-stimulating factor and prior chemotherapy on the immunological response to a vaccine (ALVAC-CEA B7.1) in patients with metastatic carcinoma. Clin Cancer Res 2001, 7:1181-1191.

69. Beck K, Blansfield J, Tran KQ, Feldman AL, Hughes MS, Royal RE, Kammula US, Topalian SL, Sherry RM, Kleiner D, Quezado M, Lowy I, Yellin M, Rosenberg SA, Yang JC: Enterocolitis in patients with cancer after antibody blockade of cytotoxic T-lymphocyte-associated antigen 4 . J Clin Oncol 2006, 24:2283-2289.

70. Zou W: Regulatory T cells, tumour immunity and immunotherapy. Nat Rev Immunol 2006, 6.295-307.

71. Ghiringhelli F, Menard C, Puig PE, Ladoire S, Roux S, Martin F, Solary E, Le Cesne A, Zitvogel L, Chauffert B: Metronomic cyclophosphamide regimen selectively depletes CD4+CD25+ regulatory $T$ cells and restores $T$ and NK effector functions in end stage cancer patients. Cancer Immunol Immunother 2006, 56:641-648.

72. Attia P, Maker AV, Haworth LR, Rogers-Freezer L, Rosenberg SA: Inability of a fusion protein of IL-2 and diphtheria toxin (Denileukin Diftitox, DAB389IL-2, ONTAK) to eliminate regulatory T lymphocytes in patients with melanoma. J Immunother 2005, 28:582-592.

73. O'Mahony D, Morris JC, Quinn C, Gao W, Wilson WH, Gause B, Gause B, Pittaluga S, Neelapu S, Brown M, Fleisher TA, Gulley JL, Schlom J, Nussenblatt R, Albert P, Davis TA, Lowy I, Petrus M, Waldmann TA, Janik JE: 
A pilot study of CTLA-4 blockade after cancer vaccine failure in patients with advanced malignancy. Clin Cancer Res 2007, 13:958-964.

74. Dannull J, Su Z, Rizzieri D, Yang BK, Coleman D, Yancey D, Zhang A,

Dahm P, Chao N, Gilboa E, Vieweg J: Enhancement of vaccine-mediated antitumor immunity in cancer patients after depletion of regulatory $\mathrm{T}$ cells. J Clin Invest 2005, 115:3623-3633.

75. Idenoue S, Hirohashi Y, Torigoe T, Sato Y, Tamura Y, Hariu H, Yamamoto M, Kurotaki T, Tsuruma T, Asanuma H, Kanaseki T, Ikeda H, Kashiwagi K, Okazaki M, Sasaki K, Sato T, Ohmura T, Hata F, Yamaguchi K, Hirata K, Sato N: A potent immunogenic general cancer vaccine that targets survivin, an inhibitor of apoptosis proteins. Clin Cancer Res 2005, 11:1474-8142.

76. Donnelly JJ, Ulmer JB, Shiver JW, Liu MA: DNA vaccines. Annu Rev Immunol 1997, 15:617-648.

doi:10.1186/1479-5876-9-17

Cite this article as: Rao et al: Clinical outcomes of active specific

immunotherapy in advanced colorectal cancer and suspected minimal residual colorectal cancer: a meta-analysis and system review. Journal of Translational Medicine 2011 9:17.

\section{Submit your next manuscript to BioMed Central} and take full advantage of:

- Convenient online submission

- Thorough peer review

- No space constraints or color figure charges

- Immediate publication on acceptance

- Inclusion in PubMed, CAS, Scopus and Google Scholar

- Research which is freely available for redistribution

Submit your manuscript at www.biomedcentral.com/submit 